\title{
Ischial Tuberosity
}

National Cancer Institute

\section{Source}

National Cancer Institute. Ischial Tuberosity. NCI Thesaurus. Code C105446.

The bony prominence of the lower part of the ischium. 